\title{
THE ROLE OF ETHNOCENTRISM IN BUYING PROCESS OF THE DOMESTIC PRODUCT
}

\author{
Dewantika Noor Hidayati Kusmono, SE, MM; Dr. Budhi Haryanto, MM. \\ Post Graduate of Magister Management Sebelas Maret University Surakarta, Ir Sutami Street No 36A \\ Kentingan, Surakarta \\ dewantikanhk@yahoo.com \\ Faculty of Business and Economic, Sebelas Maret University Surakarta, Ir Sutami Street No 36A Kentingan, \\ Surakarta \\ budhiharyanto@yahoo.com
}

\begin{abstract}
The increase trend of globalization and advance technology in communication and transportation enable the consumers to access great variety of products and services from other countries. The competition between domestic and foreign corporations became interesting to be studied. The objective of this research explains the relationship among of the observed variables. There are six relationship, namely, perceived quality and price fairness toward consumer attitudes toward domestic product, consumer attitudes toward intention to buy domestic product. Last, role of ethnocentrism as the moderation in this research. The data is collected by survey and guided by questionnaire to 250 respondents. The survey is conducted in Yogyakarta by using a convenience sampling method. The constructed model were measured using five point Likert scale. The findings show that consumer attitudes toward Leather Bag in Manding is influenced by price fairness and perceived quality. In the relationship between perceived quality, price fairness, consumer attitudes, and intention to buy, the ethnocentrism did not play a moderation role.
\end{abstract}

\section{INDEXING TERMS / KEYWORDS}

Ethnocentrism, Consumer Attitudes, Domestic, Intention to buy, Perceived quality, Price Fairness.

\section{ACADEMIC DISCIPLINE AND SUB-DISCIPLINE}

Economic, Management, Marketing

\section{SUBJECT CLASSIFICATION}

Marketing subject classification

TYPE (METHOD/APPROACH)

Survey

\section{Council for Innovative Research}

\section{Peer Review Research Publishing System}

\section{Journal: Journal of Social Sciences Research}

Vol. 8, No.1

jssreditor.cir@gmail.com

www.jssronline.com 


\section{INTRODUCTION}

The study of consumer attitudes toward domestic product is interesting to be studied because it can be used to improve the insights about decision variables that influence consumer's attitudes toward domestic product. This research also can be used as reference in discussing the theory on marketing area, especially on consumer attitudes and ethnocentrism. Besides, the preview study indicated some limitation related to the scope of study and geographical location. So it gives the opportunity to built an alternative model which can explain according to the observed setting.

In the model, there is a phenomenon which can be used as a support background research explanation. In this study, the phenomenon of the increase trend of globalization and advance technology in communication and transportation enable the consumers to access and be exposed to a great variety of products and services from other countries. Previous studies found that consumers often evaluate the products of foreign origin differently than they do to domestic products. Specifically, consumers in developed countries have a general preference for domestic made products over foreign products while consumers in developing countries are more likely to prefer foreign products than domestic ones as they believed foreign products were more superior than domestic products in quality and using foreign products will impress others as they were associated with high fashion or high social status (Wang, 2004). However, the culture to appreciate domestic product has a strong influence on consumers in Indonesia. Most of the consumers prefer to buy local products eventhough their quality is lower than foreign brands (Jianlin et al, 2010). It caused by the role of ethnocentrism.

This study consists of five variables. Namely perceived quality, price fairness, consumer attitudes, ethnocentrism, and intention to buy domestic product. Perceived quality and price fairness are antecedent variables of consumer attitudes toward domestic product, it means in order to increase consumer attitudes marketer must stimulate the antacedent variables which express on marketing strategy to be done (Bloch, 1983). The next variable in this context is consumer attitude toward domestic product, it is contructed as mediation variable in the model. It means that attitude mediates between antacedent variables and intention to buy (Angel et al, 2001). The fourth variable is ethnocentrism as moderator variable that affects the direction of the relation between perceived quality and price toward and consumer attitude toward domestic product. Latest, intention to buy is a dependent variable which is predicted in this study. It is done in order to predict how big the actual behaviour toward domestic product throught this variables (Zheitaml et al, 1996).

The first variable is perceived quality. Perceived quality can be defined as the customer's judgement about the product's overall excelence or priority (Zeithaml, 1988). The preview study indicated that perceived quality have been influenced consumer preference toward domestic product. This is evidenced by research of Steenkamp et al. (2003) which indicated that consumers value global brands especially for their assumed high quality and prestigious image. Based on the previous research the brand is perceived as globally available, consumers are likely to attribute a superior quality to the brand, since such quality is thought of as a prerequisite for international acceptance (Ismail et al., 2012). So, this variable can be influencing consumer preference toward domestic product.

The next variable is price fairness. Based on preview study, consumers have differences to perceived a price between local-owned and foreign-owned brands, price dissimilarities begin to affect their preference for local-owned brands. Therefore, since price is also one of the most important extrinsic cues that consumers use when evaluating the product/brand, they tested the impact of price against consumer's ethnocentric tendencies to determine at what point consumers are willing to forsake preference for local products for a greater price discount with foreign owned products (Hansen, 2005). Hence, this variable can be influencing consumer attitude toward domestic product.

The next variable is consumer attitudes. This variable is predicted in influencing the intention to buy domestic product. Attitude is an overall persistent evaluation towards people, things, or goods (Engel et al., 2006). Brand attitude is the continuous preference or loathing tendency of the consumer towards a certain brand and the overall evaluation the consumer has towards the brand (Fishbein and Ajzen, 1980). If attitudes and behavior are highly correlated, then the behavior of a person can be predicted once her/his attitude has been established (Ajzen \& Fishbein, 1977). Hence, this variable can be used as mediation variable that influencing of the relation between perceived quality and price fairness toward intention to buy domestic product.

The next variable is ethnocentrism. Ethnocentrism is defined as the beliefs of consumers about the appropriateness, indeed morality of purchasing foreign made products (Shimp and Sharma, 1987). Consumers in developed countries tend to prefer their own country's products, a phenomenon that is labelled consumer ethnocentrism (Hong et al, 1989). Moreover, the perception from the perspective of consumers in developed countries that products from developing countries are often of low or variable quality (Andaleeb, 1995). The consumers with higher consumer ethnocentrism have better attitude toward domestic products. When consumers have positive product attitude, it means that they judge the products better and have stronger purchase intention (Jianlin et al, 2010). Hence, it can be used as moderation variable that affects the direction of the relation between perceived quality, price and consumer attitudes toward domestic product. The last variable is intention to buy domestic product. Based on the the preview study literature, Lavidge and Steiner introduced The Stair-Step model that explained consumer behavior toward intention to purchase. The rationale behind this model is beliefs are formed about a brand or a product, influenced by those beliefs, attitudes toward the brand or the product are consequently formed, and finally, from these attitudes individuals will develop an intention to buy or not buy the particular brand or product (Guilabert, 2005).

\section{THEORITICAL FRAMEWORK AND HYPOTHESIS}

\section{The Consumer Attitudes}

Consumer attitude is commonly defned as consumers'overall evaluative judgment of a product's attributes such as style, brand, and quality" (Erdogan \& Uzkurt, 2010). Most of a brand's characteristics are associated with its country of origin. According to Kaynak \& Kara (2002) since the customers evaluate products based on all the information available to them, even though such information is very little the country of origin becomes a critical determinant of consumer's product evaluation. Furthermore, Huddleston, Linda \& Lesli (2001), noted that the country of origin indicates the quality of products based on intrinsic (style, material) and extrinsic (price and brands) cues. Furthermore, Lantz \& Loeb (1996) explored that 
the conutry of origin is more important than the brand name, price, and quality in shaping attitudes towards the particular product. However, some researchers argue that domestic customers may develop favorable attitudes towards the products that come from countries with similar cultural, political and economic conditions (Kaynak \& Cavusgil, 1983).

In contrast, preferences for local brands are derived from consumer ethnocentrism and domestic country (Shimp et al, 1987). The previous study stated that the consumer preferences of a product's country of origin are based on their knowledge towards the products and the brand which is their cognitions, the positive and negative attitudes towards the contry of origin which is consumer affect and conative behaviour which is when the consumers actually buy the foreign products (Papadoupoulos et al., 1993). Conclusively, country of origin has a major impact on consumer preferences especially in the fashion industry.

In the model, consumer attitudes is positioned as the moderator variable as mediation variable that influencing of the relation between perceived quality and price fairness toward intention to buy domestic product. Besides, the role of ethnocentrism can be defined as moderator on the relation between consumer attitudes toward both independent variables, perceived quality and price fairness. Hence, the explanation of each variable on definition and relationship among of variables.

\section{The Perceived of Quality}

The perceived quality can be defined as a global assessment ranging from bad to good, characterized by a high abstraction level and refers to a specific consumption setting for its users (Monroe et al, 1985). According to Kirmani and Baumgartner (2000), perceived quality is defined as a consumer's evaluation of a brand's overall excellence based on intrinsic (i.e. performance, durability) and extrinsic cues (i.e. brand name, warranty). Perceived quality also can be defined as the consumers's judgment about an entities or services overall excellence or superiority (Zeithaml, 1988). It means that if a brand is viewable as globally available, consumers may attribute higher quality to the brand because such quality is likely to be thought of as critical to global acceptance (Kapferer, 1997).

As conceptualized, perceived quality as one of the important variable which can be influenced by consumer's preference toward domestic product. So, perceived quality is a special type of association, because it can be influence toward brand associations in many contexts and it has been empirically shown to affect profitability (Aaker et al, 2000). The previous study indicated that respondents could be swayed to choose foreign products if quality and price considerations were sufficiently favourable (Kaynak and Cavusgil, 1983). Specifically, they observed that consumers might not accept inferior quality domestic products when superior foreign products are available. They concluded that consumer attitudes toward products of foreign origin vary significantly across product classes. Perceived qulity is the subjective judgment of consumers toward a product or brand's superiority and distinction (Akram, 2011). So, perceived quality as an important variable in determining consumer preference toward domestic product (Milberg, 2008).

Furthermore, consumers may attribute lower quality to the domestic product than foreign product. So, the perceived quality allegedly have a negative relation to consumer attitudes toward domestic product. Thus, the phenomenon leads to formulated hypothesis as follow : $\mathrm{H} 1$ : The higher perceived quality is being the lower consumer attitudes toward domestic product.

\section{The Perceived of Price Fairness}

The perceived of price is the customer's perceptual subjective perception of the objective price of the product or service (Chang et al,1994). The fairness can be defined as a judgement of wether an outcome or the process to reach and outcome are reasonable and acceptable (Bolton et al, 2003). Conceptually, perceived price fairness is defined as consumer's assesment of wether a seller's price can be reasonably justified (Xia et al, 2004). Perceived price fairness can also defined by the perceived of consumers about the benefits offered by the product relative to the sacrifice is favourable and the consumers will be more likely to perceive that the price is fair (Monroe, 2003). So consumer tend to rely on several reference points such as past prices, competitor's prices, and cost of goods sold when inferring price fairness to make comparison (Bolton et al, 2003). Thus, the perceived price fairness also can be defined as the reasonable and rational price (Schein, 2002)

The previous study indicated that consumers perceived a price difference between domestic and foreign brands, price dissimilarities begin to affect their preference for domestic brands (Hansen, 2005). Hence, price is considered as a variable that have positive correlation on consumer attitudes toward domestic product.

Based on the explanation leads the next hypothesis : H2 : The higher perceived price fairness is being the higher consumer attitudes toward domestic product.

The Purchase Intention

The purchase intention shows customers preference to purchase the product, whose image is very close to customer. Moreover customers are well aware of certain brand name through advertising, from their past experience or information form their friends and relatives (Teng, 2008). The intention of a consumer to purchase a particular brand can be defined as his willingness to buy product (Teng, 2008). Purchase intention has been widely in the literature as a predictor of subsequent purchasing. Literature suggests that the identification of consumers with a company or brand can result into positive attitudinal and/or behavioral outcomes. Aaker and Keller (1990) mentioned that a brand with high awareness and good image can promote brand loyalty to consumers, and the higher the brand awareness is, the higher brand trust and purchase intention are to consumers. Consumers will have a higher purchase intention with a familiar brand. Likewise, if a product has higher brand awareness it will have a higher market share and a better quality evaluation. A well known brand will have a higher purchase intention than a less well known brand. Hence, the last hypothesis is formulated as follow : H3 : The higher consumer attitudes toward domestic product is being the higher intention to buy domestic product. The Ethnocentrism

Consumer ethnocentrism is defined as the beliefs of consumers about the appropriateness, indeed morality of purchasing foreign made products (Shimp and Sharma, 1987). It also can be defined that consumer ethnocentrism is a psychological construct which represents how consumer's point of view about products made in their own country markets as objects of 
pride and identity versus those from other country markets (Kinra, 2006). Consumer characteristics such as nationalism and domestic country preference have been known to have a moderating influence on foreign brands (Shimp et al., 1987). In the model, ethnocentrism can be indicated as a moderator of the influencing between antacedent variables on consumer attitudes toward domestic products. The moderating influence on foreign brands is consistent with the fact that consumer ethnocentrism is contingent not only on the domestic country culture that espouses it, but also the quality of domestic products coming from it (Kinra, 2006). Ethnocentric consumers may even be willing to sacrifice objective gain to enjoy the psychological benefit of avoiding contact with the out-group by purchasing local brands (Baughn et al.,1996).

The previous studies supported that there are an influence nationality as moderation between perceived quality and price fairness toward consumer preference between foreign or domestic products. According to Hsieh (2004) indicated that ethnocentrism is not only support the nation that consumers tend to have a stronger preference for products that originate in their own countries, but also they are concur with the proposition that consumers also tend to have a stronger preference for products from countries in the same geographic region. Consequently, the images of a foreign country that are formed by consumers are made of cognitive, affective and behavioral components (Kaynak et al.,1983). According Wang et al. (1980) found that consumers in developed countries tend to prefer their own locally-produced goods, followed by products from other developed countries, and then products from less developed countries.

Furthermore, ethnocentric consumers take pride in their country's brands, symbols, and culture (Steenkamp et al, 2003). Purchasing foreign made products may be seen as immoral and unpatriotic because it has an adverse impact on the domestic economy, hence, consumers tend to purchase local products even if the quality is lower than that of imports (Wall et al, 1986). So, nationality can be defined as substantial implications for consumer attitude formation towards foreign products/brands, their purchase intentions and choice between domestic versus foreign-made products (Reardon et al, 2005).

Based on the explanation leads the next hypothesis $\mathrm{H} 4$ : The higher ethnocentrism strenghten on the relation between perceived quality and consumer attitudes toward domestic product.

In the model explain that higher nationality, reinforce on the relation between price fairness and consumer toward local product. So consumer with the high nationality tends to choose local brand because the price is usually lower than foreign products. In turn, without nationality, consumer tends to choose foreign product (Xia et al, 2004). So, the relationship between price fairness and consumer preferences toward local brand can be reinforced with the nationality. Hence, the phenomenon can be formulated the hypothesis as follow H5 : The higher ethnocentrism strenghten on the relation between price fairness and consumer attitude toward domestic product.

According to Peter et al. (2008) the effects of ethnocentrism on consumer attitudes and purchase intention have been used in several in theoretical explanation for how consumer acquire, process, and use as a cues. Based of the explanation leads the next hypothesis $\mathrm{H} 6$ : The higher ethnocentrism strenghten on the relation between consumer attitude and intention to buy domestic product.

\section{THERESEARCH MODEL}

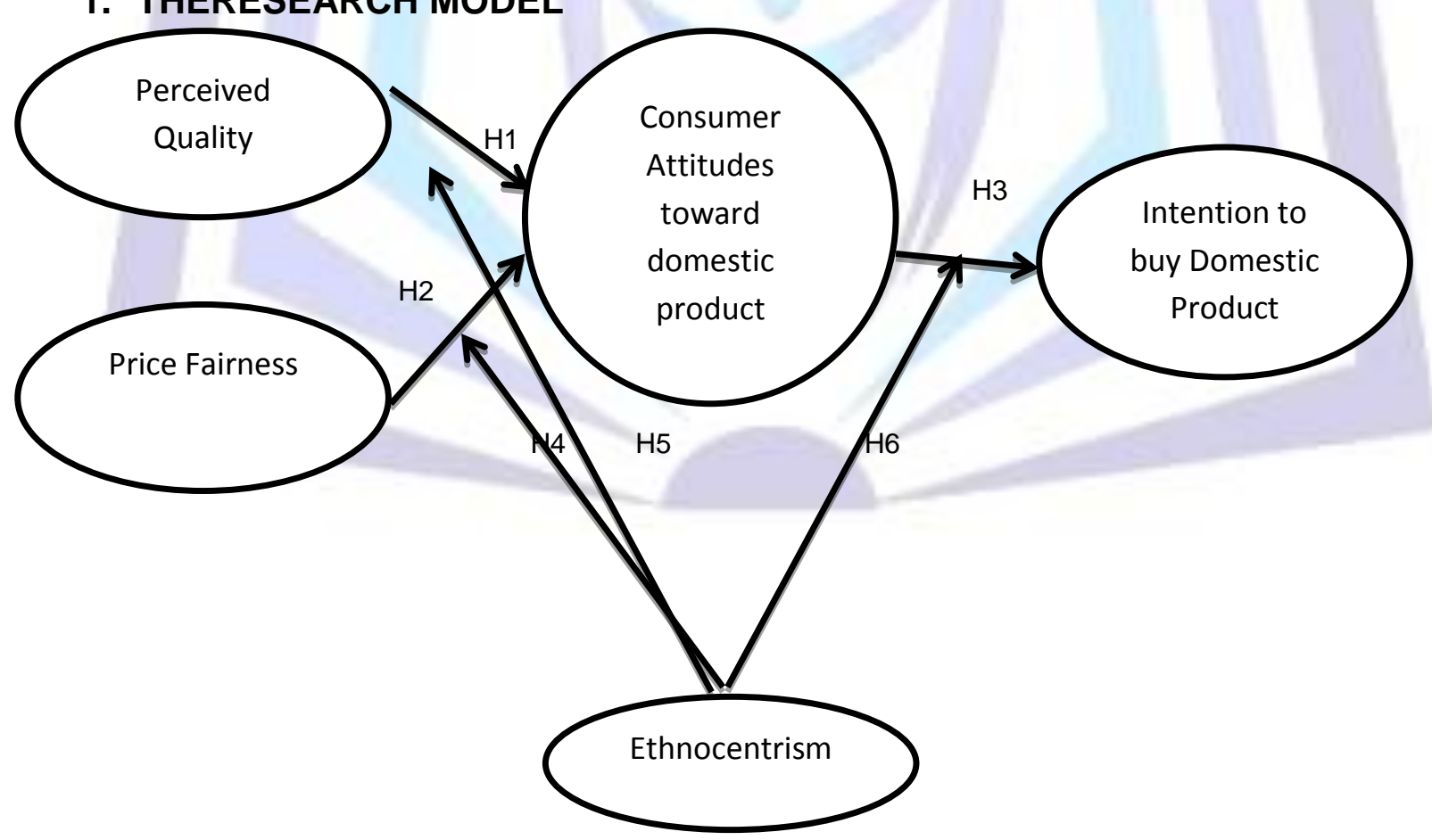

Figure 1. The Model of The Buying Process Toward Domestic Product

\section{THE RESEARCH METHOD}

\section{The Sampling and The Data Collection Method}

Population of this study is individuals who have intention to buy the domestic of leather bag at Manding, Yogyakarta. The 
sample consists of 250 respondents by using convenience method.

The data are collected by giving the questionnaire to participants who sit and walk around of Manding and Maliobro Street, the questionnaire were then asked to returm immadietly, if all the items have been fulfilled.

\section{The Definition}

Perceived quality is a specific concept based on product and service features (Rust and Oliver, 1994). The indicators is measured by Likert scale that ranged from $1=$ strongly disagree until $5=$ strongly agree. Furthermore, in the context of the foreign product, these variables are operationalized into four items : Good design, reliable, durability, not easily damaged. The price fairness is defined as consumer's assesment of wether a seller's price can be reasonably justified (Xia et al, 2004). The indicators is measured by Likert scale that ranged from $1=$ strongly disagree until $5=$ strongly agree. Following is the indicators of this variable : Logic, rational, reasonable, acceptable.

Consumer ethnocentrism is a psychological construct which represents how consumer's point of view about products made in their own country markets as objects of pride and identity versus those from other country markets (Kinra, 2006). The indicators is measured by Likert scale that ranged from $1=$ strongly disagree until $5=$ strongly agree. Hence, the indicators of this variable are : Sense of nationality, devotion of domestic poduct, the image of domestic product, the pride using domestic product.

Attitude is an overall persistent evaluation towards people, things, or goods. It is a consistent positive or negative reaction towards certain things through learning, which includes favorable or unfavorable evaluation, emotional feeling, and behavioral tendency (Kotler and Keller, 2008). The indicators is measured by Likert scale that ranged from $1=$ strongly disagree until $5=$ strongly agree. The indicators of this variable are : Benefit of domestic product, better choice, like, enthusiastic.

The intention of a consumer to purchase a particular brand can be defined as willingness to buy product (Teng, 2008). ). The indicators is measured by Likert scale that ranged from $1=$ strongly disagree until $5=$ strongly agree. The indicators of this variable are : Probability, preference, likely, propensity.

\section{Analysis Method}

The study used SEM analysis in order to elaborate the relationship among of observed variables.

\section{RESULTS}

\section{Relationship between perceived quality and consumer attitudes}

The test results indicated a significant and positive relationship between perceive quality and consumer attitudes $(\beta=$ $0.365, \mathrm{CR}=5.526, \mathrm{SE}=0.066$ ) (See Table 1). This explains that the higher perceive quality, the lower consumer attitudes. Hence, the findings of this study supported the hypothesis 1 that describes a significant and negative relationship between perceived quality and consumer attitudes.

The perceived quality is consumers' assessment of overall excellence or superiority of a product (Zeithaml, 1988). It can defined as perceived product quality is a global assessment from bad to good, characterized by a high level of abstraction and refers to the specific consumption setting. The previous study indicated that respondents held positive attitudes towards products made in their own country but the same respondents could be swayed to choose foreign products if quality and price considerations were sufficiently favourable (Kaynak and Cavusgil, 1983). So, this study is provided support for the previous research that the higher perceived quality, the lower the consumer attitudes toward domestic product.

Practically, marketer can utilize these findings to develop marketing strategies associated with the method of determining the perceived quality in the relationship with consumer attitudes. Specifically, it is expected to provide an understanding of the domestic product marketers associated with the concept of consumer attitudes toward domestic product, especially Leather bag. So the domestic marketer can enhance the quality of their products to improve the sales of leather domestic product and can be competed with foreign product.

For further research, the result shows that the findings is supported the hyphotesis, hence, the concept was hyphotesized that still requires.

\section{Relationship between perceived price fairness and consumer attitudes}

The test results indicated a significant and positive relationship between prestige and consumer attitudes $(\beta=0.220$, CR $=$ 4.136, $S E=0.053$ ) (See Table 1). The test results indicated a significant and positive relationship between price fairness and consumer attitudes $(\beta=0.220, C R=4.136, S E=0.053)$ (See Table 1). This explains that the higher price fairness, the higher consumer attitudes.

Perceived price fairness can also defined by the perceived of consumers about the benefits offered by the product relative to the sacrifice is favourable and the consumers will be more likely to perceive that the price is fair (Monroe, 2003). The previous study indicated that consumers perceived a price difference between domestic and foreign brands, price dissimilarities begin to affect their preference for domestic brands (Hansen, 2005). Therefore, the findings of this study support the hypothesis 2 that describes a significant and positive relationship between price fairness and consumer attitudes.

This research is expected to improve knowledge of the academics associated with the relationship of price fairness toward consumer attitudes. Specifically, it is expected to provide an understanding of the importance of price fairness domestic 
product. So, marketers can be use price fairness as their strenght to promote their product. It is expected to improve the sales of leather domestic product and can be competed with foreign products.

For future research, it is expected to conduct examination of the relationship between price fairness and consumer attitudes. By entering ethnocentrism, it is expected to find an explanation empirically outcame.

\section{Relationship between intention to buy and consumer attitudes}

The test results indicated a significant and positif relationship between usefulness and consumer attitudes $(\beta=1.246$, CR $=7.164$, $\mathrm{SE}=0.174$ ) (see table 1). It means that the higher consumer attitudes higher the intention to buy. Hence, the findings of this study support the hypothesis 3 that describes a significant and positif relationship between consumer attitudes and intention to buy.

The phenomenon could happen because consumer beliefs are formed about a brand or a product; secondly, influenced by those beliefs, attitudes toward the brand or the product are consequently formed; and finally, from these attitudes individuals will develop an intention to buy or not buy the particular brand or product (Gulabert,2005). Based on the explanation above, it can conclude that the hyphotesis support the previous study that there is positif relationship between consumer attitudes and intention to buy.

Practically, this research is expected to improve understanding of the academics associated with the relationship of consumer attitudes toward intention to buy domestic product. Specifically, it is expected to provide an understanding of the relationship between consumer attitudes toward intention to buy domestic products. So, marketers can be used to develop strategies to be able to compete the foreign product.

For future research, the hyphotesis in the research is supported but it needs further research are different in term of context and scope. This is necessary in order to find the different level of generalization theory, which can contribute both practically and theoretically.

Table 1. Regression Weights Toward Consumer Attitudes

\begin{tabular}{|c|c|c|c|c|c|}
\hline & 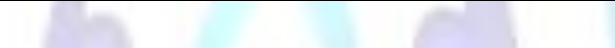 & Estimate & S.E. & C.R. & $P$ \\
\hline $\begin{array}{l}\text { Consumer Attitudes toward domestic } \\
\text { product }\end{array}$ & <--- Perceived Quality & .365 & .066 & 5.526 & *** \\
\hline $\begin{array}{l}\text { Consumer Attitudes toward domestic } \\
\text { product }\end{array}$ & Price Fairness & .220 & .053 & 4.136 & $* * *$ \\
\hline Intention to buy Domestic Product & $\begin{array}{l}\text { Consumer Attitudes toward domestic } \\
\text { product }\end{array}$ & 1.246 & .174 & 7.164 & $* * *$ \\
\hline
\end{tabular}

$\begin{array}{ll}x^{2} \text { chi square } & 148.488 \\ x^{2} \text { significance probability } & .052 \\ \text { GFI } & 0.941 \\ \text { RMSEA } & 0,030 \\ \text { AGFI } & 0.917 \\ T L I & 0.989 \\ C F I & 0.991 \\ C M I N / D F & 1.217\end{array}$

${ }^{*}$ significant at level $10 \% ;{ }^{* *}$ significant at level $5 \% ;{ }^{* * *}$ significant at level $1 \%$

\section{The Role of Ethnocentrism In Moderating Relationship between Perceived Quality and Consumer} Attitudes

The estimated value effect on perceived quality toward consumer attitudes in high ethnocentrism groups and low ethnocentrism groups differed lower but significant in the amount of 0.408 and 0.267 (see table 2). It indicates that ethnocentrism moderating variables has a moderat effect in perceived quality toward consumer attitudes because the differences in the estimated value reached 0.141 or $14.1 \%$ (see table 2 ).

The estimated value effect of price fairness on consumer attitudes in high ethnocentrism groups and low ethnocentrism groups did not differ much lower but significant, namely 0.169 and 0.127 . It showed that there is no effect of moderating ethnocentrism variables because the estimated values in the two groups did not differ much, only about 0.069 or 6.9. 
Table 2. The Result of Moderation Analysis

\begin{tabular}{|c|c|c|c|c|c|c|}
\hline \multirow{2}{*}{ Variabel } & \multicolumn{3}{|c|}{ high ethnocentrism } & \multicolumn{3}{|c|}{ low ethnocentrism } \\
\hline & Est. & SE & Sig. & Est. & SE & Sig. \\
\hline $\begin{array}{l}\text { Perceived quality } \rightarrow \text { consumer } \\
\text { attitudes }\end{array}$ & 0,408 & 0,078 & $* * *$ & 0,267 & 0,123 & 0,030 \\
\hline $\begin{array}{l}\text { Perceived price fairness } \rightarrow \\
\text { consumer attitudes }\end{array}$ & 0,196 & 0,068 & 0,004 & 0,127 & 0,067 & 0,058 \\
\hline $\begin{array}{l}\text { Consumer attitudes } \rightarrow \text { intention } \\
\text { to buy }\end{array}$ & 1,181 & 0,189 & $* * *$ & 1,812 & 0,752 & 0,016 \\
\hline & \multicolumn{6}{|c|}{ Comparison Goodness of Fit } \\
\hline Chi square & \multicolumn{6}{|c|}{$271,369-269,926=1,443$} \\
\hline Degree of Freedom & \multicolumn{6}{|c|}{$243-240=3$} \\
\hline \multirow[t]{2}{*}{ Probability } & \multicolumn{6}{|c|}{0.750} \\
\hline & \multicolumn{6}{|c|}{$\geq 0,05$} \\
\hline
\end{tabular}

Based on the previous study indicated that consumer with the high ethnocentrism tends to choose local brand because the price is usually lower than foreign products. In turn, without nationality, consumer tends to choose foreign product (Xia et al, 2004). So, the hyphotesis is supported the previous study.

Practically, the findings is expected to increase knowledge of the academics associated with the role of ethnocentrism to the relationship of price fairness toward consumer attitudes. Specifically, it is expected to provide an understanding of the domestic product marketers associated with the concept of ethnocentrism toward the relationship between price fairness and consumer attitudes toward domestic product, especially Leather bag. So the domestic marketer can enhance price fairness as their strenght to improve the sales of leather domestic product and can be competed with foreign product.

For researchers in the future, these findings still require a generalization of the concept hyphotesized. Therefore, further tests are needed in different contexts. This study can be used as a reference in designing research measurement following measurement variales and testing methods.

\section{The Role of Ethnocentrism In Moderating Relationship between Price Fairness and Consumer Attitudes}

The estimated value of consumer attitudes influence on the intention to buy in the high ethnocentrism groups and low ethnocentrism groups are moderate differ significantly by 1,181 and 1,812. This suggests that ethnocentrism variables has high moderating effect in consumer attitudes influence on intention to buy because of differences in the estimated value reached 0.631 or $63.1 \%$. Based on the explanation above, there are different grades showed moderate estimate the estimated value of consumer attitudes influence on intention to buy in high ethnocentrism groups than low ethnocentrism gruops that there is possible moderating effects of consumer ethnocentrism in relation to consumer attitudes and intention to buy.

According to Peter et al. (2008) the effects of ethnocentrism on consumer attitudes and purchase intention have been used in several in theoretical explanation for how consumer acquire, process, and use as a cues. It can be conclude that the hyphotesis is supported the previous study that there is possible moderating effects of consumer ethnocentrism in relation to consumer attitudes and intention to buy.

For practitioners, this research is expected to improve understanding of the academics associated the role of ethnocentrism to the relationship of consumer attitudes toward intention to buy domestic product. Specifically, it is expected to provide an understanding of the role of ethnocentrism to the relationship between consumer attitudes toward intention to buy domestic products. So, marketers can be used to develop strategies to be able to compete the foreign product.

The research is focused in Manding, Yogyakarta that impact on limitation of the model generalization. So, the consumer attitudes of one place to another can not be equated. So, it needed continuing explanation, especially on developing the measurement in another setting.

But in general, ethnocentrism variable does not moderate the relation of causality perceived quality and price fairness on consumer attitudes and consumer attitudes on the intention to buy, the table shows that proaility value is higher than $\geq$ 0,05 , so it can be concluded hypothesis 4,5 , and 6 are not supported.

\section{CONCLUSION AND IMPLICATION}

\section{Conclusion}

The purpose of this study is to explain the correlation among of the observed variables. First, the influence of perceived quality and price fairness toward consumer attitudes toward domestic product; the influence of consumer attitudes toward intention to buy domestic product; and the moderation roles on the relationship among variables. In summary, consumer attitudes toward Leather Bag in Manding is influenced by price fairness and perceived quality. However, perceived quality has a negative effect on consumer attituddes toward leather bag in Manding. In the relationship between perceived 
quality, price fairness, consumer attitudes, and intention to buy, the ethnocentrism did not play a moderation role. It means that ethnocentrism variable does not moderate the relation of causality perceived quality and price fairness on consumer attitudes and consumer attitudes on the intention to buy.

Implication

Theoretically, this research is expected to improve understanding of the academics associated with the concept of consumer attitudes toward domestic product. It is based on the uniqueness in this research that gives a different perspective than previous studies. The uniqueness can be known from the observations variables that being modeled and adjusted to research setting in Indonesia. Furthermore, this research is also expected to be discussed further, so it can be developed and tested in different research settings.

Practically, the result is expected to provide an understanding of the domestic product marketers associated with the concept of consumer attitudes toward domestic product, especially Leather bag. Understanding the consumer attitudes toward Leather Bag can be used in understanding the attitudes and set a strategy to increase sales in Indonesia. This study can be used as a reference to innovate on what customers want for domestic manufacturers. This study concerns on only a domestic alternative but to the foreign product is unavailable. In such situations, the use of ethnocentrism information may be strategically advantageous for domestic manufactures. Consequently, the emphasis of ethnocentrism for domestic products will not be harmful and it can be beneficial to sales. Moreover this research can be used as reference in discussing the theory on marketing area, especially on consumer attitudes toward domestic product. Moreover, this study is hoped could enrich theoritical understanding in marketing study.

For future study, this study object is focused on people in Yogyakarta, that impact on limitation of the model generalization. This condition gives an opportunity for continues study, especially in developing the model on wider context. It is important because this study has a limited application. So, it needed continuing explanation, especially on developing the measurement in another setting.

\section{REFERENCE}

(1) Aaker, D. A., Kumar V. 2000. Marketing Research 7th Edition. New York : John Willey and Sons.

(2) Aaker, D. A., Keller, K.L. 1990. Consumer Evaluation of Brand Extansions. Journal of Marketing. Vol 54 No 1, pp 27-41.

(3) Agrawal, J., Kamakura, W. A. 1999. Country of origin : A competitive advantage. International Journal of Research in Marketing. Vol. 16, No. 4, pp. 255-267.

(4) Ajzen, I., Fishbein, M. 1980. Understanding Attitudes and Predicting Social Behaviour. Englewoods Clifss NJ : Prentice Hall Inc.

(5) Ajzen, I., Fishbein, M. 1977. Attitude Behaviour Relations : A Theoritical Analysis and Review of Empirical Research. Psychology Bulletin. 84 pp 888-918

(6) Alba, Joseph W. and J.W. Hutchinson. 1989. Dimensions of Consumer Expertise. Journal of Consumer Research. 13 (4), 411-54.

(7) Andaleeb, Syed Saad. 1995. Country-of-Origin Effects: A Country-Category Effect Hypothesis. Journal of International Consumer Marketing, 7 (3), 29-52.

(8) Angel, J. F; Roger, D; Well, Black. 2001. Perilaku Konsumen Edisi ke 6 Jilid 1. Jakarta: Binarupa Aksara.

(9) Akram, A; Merunka, D; Akram, M.S. 2011. Perceived brand globalness in emerging markets and the moderating role of consumer ethnocentrism. International Journal of Emerging Markets, vol. 6, no. 4, pp. 291-303.

(10) Allport, G.W. 1935. Attitudes in Handbook For Social Psychology. C. Murchison Edition. Worcester : Clarc University Press.

(11) Azzawi, Maha Al., Mac Anthony N.E. 2012. Student Brand Preferences Beween Apple and Samsung Smartphone. Thesis. Vasteras : School of Sustainable Development of Society and Technology Malardalem University Eskilstuna, Vasteras.

(12) Batra, R; Ramaswamy, V; Alden, D. L; Steenkamp, J. B. E. M; Ramachander, S. 2000. Effects of Brand Local and Nonlocal Origin on Consumer Attitudes in Developing Countries. Journal of Consumer Psychology, 9(2), 83 $-95$.

(13) Baughn, C.C., Yapark, A. 1996. Economic nationalism: conceptual and empirical development. Political Psychology, Vol. 17(4), pp. 759- 778.

(14) Bloch, P.H., Richins M.L. 1983. A theoritical for the study of product importance perceptions. Journal of Marketing. 47(3).

(15) Bolton, L.E; Warlop, L; Alba, J.W. 2003. Consumer Perceptions of Price (Un)Fairness. Journal of Customer Research. 29 (4), 474-491.

(16) Byne, S.F., Young, S.D. 2001. EVA dan Manajemen Berdasarkan Nilai. Jakarta : Salemba Empat.

(17) Chang, T.Z., Wildt, A.R. 1994. Price, Product Information, and Purchase Intention : Empirical Study. Journal of the Academy of Marketing Science. 22 (1). 16-27.

(18) Dmitrovic, T., I. Vida. 2010. Consumer Behaviour Induced by Product Nationality: The Evolution of the Field and its Theoretical Antecedents. Transformation in Business and Economics 9 (1): 145-65.

(19) Elliott, G. R., Cameron, R. S. 1994. Consumer perception of product quality and the country- of-origin effect. Journal of International Marketing. 2 (2): 49-62.

(20) Ergin, E. A. 2010. Consumers' Purchase Intentions For Foreign Products: An Empirical Research Study in Istanbul, Turkey. International Business and Economics Research Journal 328, pp 337-339.

(21) Engel, R.S., Johnson, R. 2006. Toward a Better Understanding of Racial and Ethnic Disparities in Search and Seizure Rates. Journal of Criminal Justice, Volume 34 : 605-617. 
(22) Erdogan, B.Z., Uzkurt, C. 2010. Effect of Ethnocentrism Tendency on Consumer's Perception of Product Attitudes For Foreign and Domestic Product. Journal of Consumer Behaviour, vol 28, pp 145-158.

(23) Ferdinand, A. 2002. Structural Equation Modelling dalam Penelitian Manajemen Edisi 2. Semarang : Seri Pustaka Kunci 03 / BP Undip.

(24) Frimpong, Samuel Kwadwo. A Comparison of Effect Between Domestic versus Foreign Brands on Consumer Purchasing Decision in Ghana. Proceedings of the 8th International Conference on Innovation \& Management. 277.

(25) Ghozali, I. 2006. Aplikasi Analisis Multivariat Dengan Program SPSS. Cetakan ke IV. Semarang : Badan Penerbit Universitas Diponegoro.

(26) Ghozali, I., Fuad. 2005. Structural Equation Modelling, Teori, Konsep, dan Program Aplikasi denngan Program Lisrel 8.54. Semarang : Badan Penerbit Universitas Diponegoro.

(27) Ghozali, I. 2008. Model Persamaan Struktural Konsep dan Aplikasi dengan Program Amos 16.0. Semarang : Badan Penerbit Universitas Diponegoro.

(28) Guilabert, Margarita B. 2005. Attitudes Toward Consumer-Customized High-Tech Products: The Role of Perceived Usefulness, Perceived Ease of Use, Technology Readiness, and Customer Customization Sensitivity. Marketing Dissertations. Paper 1

(29) Hair, Jr J.F; Ortinan, D.J. 2006. Marketing Research 3rd Edition. New York : Mc Graw-Hill.

(30) Hair, Jr J.F; Anderson, R.E; Tatahm, R. L; Black, B.C. 1998. Multivariate Data Analysis 5th Edition. Upper Saddle River: Prentice Hall.

(31) Hair, Jr J.F. 2002. Marketing Research. USA New Jersey : Prentice Hall, Pearson Education Inc.

(32) Hansen, T. 2005. Perspective on Consumer decision making : An Integrated Approach. Journal of Consumer Behaviour. Vol. 4, No. 6, pp 420-437

(33) Hong, S.T., Wyer R.S. (Jr.). 1989. Effects of Country of Origin and Product Attribute Information on Product Evaluation: An Information Processing Perspective. Journal of Consumer Behaviour. Res. 16 (2): 175-86.

(34) Hsieh, M.H; Pan, S.L; Setiono, R. 2004. Product-, corporate-, and country-image dimensions and purchase behavior: a multicountry analysis. Academy of Marketing Science. Vol. 32 No. 3, pp. 251-70

(35) Huang, J. H; Lee, B. C. Y; Ho, S.H. 2004. Consumer Attitudes Toward Gray Market Goods. International Marketing Review. Volume 21(6), 598-614.

(36) Huddleston, P; Good, L. K; Stoel, L. 2001. Consumer Ethnocentrism, Product Necessity and Polish Consumer's Percention of Quality. Journal of Retail Distribution Management, Vol 29 (5), pp 236-246.

(37) Ismail, Zeenat; Sarah Masmood; Mehmood Tawab. 2012. Factor Affecting Consumer Preference of International Brand over Local Brand. International Conference on Social Science and Humanity. Vol. 31 IACSIT Press, Singapore.

(38) Kaynak, E., Cavusgil, S.T. 1983. Consumer attitudes towards products of foreign origin: Do they vary across product classes?. International Journal of Advertising, Vol. 2, pp: 147-57.

(39) Kaynak, E., Kara, A. 2002. Consumer perceptions of foreign products. European Journal of Marketing, 36(7/8), 928-949. http://dx.doi.org/10.1108/02651330810887477

(40) Kapferer, J.N. 1997. Strategy Brand Management : Creating and Sustaining Brand Equity Long Term, 2nd Edition. London: Kogam Page Limited.

(41) Kinra, N. 2006. The effect of country-of-origin on foreign brand names in the Indian market. Journal of Marketing Marketing, 24 (1), 15-30.

(42) Kirmani, A., Baumgartner, H. 2000. Reference Points Used in Quality and Value Judgements. Marketing Letters, 11(4), pp 299-310.

(43) Kotler, Philip., Armstrong, Gerry. 2008. Prinsip Prinsip Pemasaran Jilid 1 Edisi 12. Jakarta : Erlangga.

(44) Lantz, G., Loeb, S. 1996. Country of Origin and Ethnocentrism : an Analysis of Canadian and American Preferences Using Social Indentify Theory. Association for Consumer Research, 374-378.

(45) Matos, C.A; Ituassu, C.T; Rossi, C.A.V. 2007. Consumer Attitudes toward Counterfeits: A Review and Extension. Journal of Marketing, Vol. 24 (1), pp. 36-47.

(46) Monroe, G.S., Chung, J. 2003. Exploring Social Desirability Bias. Journal of Business Ethic, Vol. 44, pp. $291-302$.

(47) Milberg, S. J., Sinn, F. 2008. Vulnerability of global brands to negative feedback effects. Journal of Business Research, 684-690.

(48) Monroe, K., Krishnan, R. 1985. The effect of price on subjective product evaluations. Lexington Books. Boston : MA, pp. 209-32.

(49) Papadoupoulos, N. H. L.A., Baossy, G. 1993. Product Country Images: Impact and Role. International Marketing. Binghampton, NY: International Business Press.

(50) Peter, J.P., Olsen, J.C. 2000. Consumer Behaviour : Perilaku Konsumen dan Strategi Pemasaran. Cetakan Pertama Edisi Bahasa Indonesia. Jakarta : Erlangga.

(51) Raerdon, J; Miller, C; Vida, I; Kim, I. The Effect of Ethnocentrism and Economic Development on The Formating Brand and ad attitude in Transitional Economies. 2005. Euroean Journal of Marketing, 39 (7.8), pp 737-754.

(52) Rust, R.T., Oliver R.L. 1994. Insight and Managerial From The Frontier. Thousands Oaks : Sage Publication.

(53) Schein, A. 2002. Concern for fair prices in the Israeli Housing Marketing. Journal of Economic Psychology. Vol. 23 (2), pp.213-230.

(54) Sekaran, Uma. 1983. Methodological and Theoretical Issues and Advancements in Cross-Cultural Research. Journal of International Business Studies. 14 (2), 61-73.

(55) Shimp, A. T., Sharma, S. 1987. Consumer Ethnocentrism : Construction and Validation of the CETSCALE. Journal of Marketing Research, 24(3), 280-289. 
(56) Steenkamp, J. B.-E; Batra, R; Alden, D. L. 2003. How perceived brand globalness creates brand value. Journal of International Business Studies, 34, 53-65.

(57) Teng, D.K; McCutchen, W. W. Jr; Swamidass, P.M. 2008. Strategic Alliance Termination and Performance : The Role of Task Complexity, Nationality, and Experience. Journal of High Technology Management Research. Vol $18(2)$.

(58) Wang, L. C., Chen, X. Z. 2004. Consumer ethnocentrism and willingness to buy domestic products in a developing country setting: testing moderating effects. Journal of Consumer Marketing, 21(6), 391-400.

(59) Wang, C.K., Lamb, C. 1980, Foreign environmental factors influencing American consumers' predisposition towards European products. Journal of the Academy of Marketing Science, Vol. 8 (4), pp. 345-67.

(60) Wall, M., Heslop, L.A. 1986. Consumer attitudes toward Canadian-made versus imported products. Journal of the Academy of Marketing Science, Vol. 14 (2), pp. 27-36.

(61) Wijaya, T. 2009. Analisis Structural Equation Modelling Untuk Penelitian Menggunakan AMOS. Yogyakarta: Badan Penerbit Universitas Atmajaya.

(62) Xia, L. Monroe, K.B., Cox, J.L. 2004. The price is Unfair! A Conceptual Framework of Price Fairness Perceptions. Journal of Marketing. 68 (4), 1-15.

(63) Zeithaml, V.A. 1988. Consumer perceptions of price, quality and value: a means-end model and synthesis of evidence. Journal of Marketing, vol. 52, pp. 2-22.

(64) Zeithaml, V.A, Berry, L. L; Parasuraman, A. 1996. The Behavioural Consequences of Service Quality. Journal of Marketing, vol. 60(2), pp. 31-46.

\section{Author biography}

Dewantika Noor Hidayati Kusmono, SE, MM

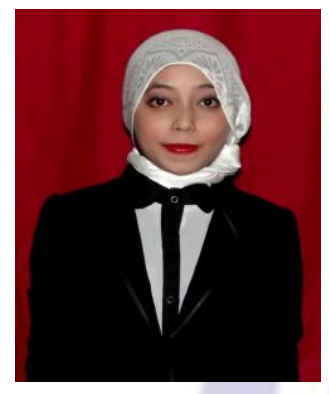

Dr. Budhi Haryanto, MM.

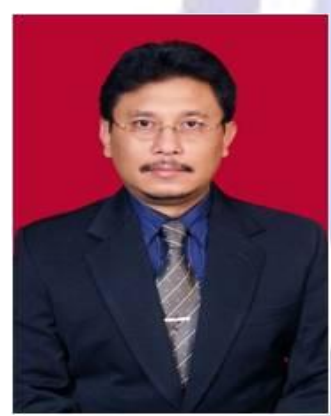

